SOIL NUTRIENT CONTENT ALTERS ARBUSCULAR MYCORRHIZAL

ASSOCIATION IN OROXYLUM INDICUM (L.) BENTH EX KURZ

GROWING UNDER DIFFERENT NATURAL HABITAT

\title{
IN NORTHEAST INDIA
}

\author{
DEBI CHANDRIMA ${ }^{1}$ \& PARKASH VIPIN ${ }^{2}$ \\ ${ }^{I}$ Research Scholar, Forest Pathology Division, Forest Research Institute, Dehradun, India \\ ${ }^{2}$ Scientist-E, Forest Pathology Division, Forest Research Institute, Dehradun, India
}

\begin{abstract}
The rhizospheric soil and roots were collected from five different sites of Northeast India, where Oroxylum indicum was naturally growing in its ecological habitat and were analysed. The study revealed that the roots of $O$. indicum were colonized with AM spores and the soil nutrient content plays a major role in the colonization of the AM spores. A total of 23 species of AM fungi belonging to four genera viz., Glomus, Acaulospora, Gigaspora, Entrophospora and Pacispora were recovered from the rhizosphere of $O$. indicum. The statistical analysis of the data revealed that the AM spore count is positively correlated with the soil nutrient status. AM spore count was maximum in forest fringe and agricultural farmland, hyphal and arbuscular colonization percentage was higher in agricultural farmland, while the vescicular colonization percentage was maximum in the rhizospheric soil of agricultural farmland and forest fringe areas. The AM spore count of $O$. indicum growing near the roadside showed positive correlation with root colonization. The correlation value of $(0.766,0.413$, and 0.567$)$ was obtained when root colonization was compared with soil organic carbon percentage, soil nitrogen and potassium content.
\end{abstract}

KEYWORDS: Oroxylum Indicum, Root Colonization, AM Spore \& Soil Nutrient Content

Received: Aug 15, 2018; Accepted: Sep 05, 2018; Published: Sep 25, 2018; Paper Id.: IJBROCT20181

\section{INTRODUCTION}

The rhizosphere is an area where the roots compete with the invading root systems of neighbouring plant species for space, water and mineral nutrients, and with soil-borne microorganisms, including bacteria, fungi, and insects feeding on an abundant source of organic material (Ryan and Delhaize, 2001). Soil acts as a habitat for a diverse group of microorganisms. Arbuscular mycorrhiza ( $\mathrm{AM} \approx \mathrm{VAM})$ is a symbiotic or mutualistic association between the roots of about $90 \%$ of the vascular species of plants. The AM fungi belong to the fungal phylumGlomeromycota (Schubler et. al, 2001). In such associations, both the partners share mutual benefits. The fungus derives nutrients via the root of the plant. In VA mycorrhizae the fungal hyphae develop some special organs called vesicles and arbuscules within the root called cortical cells. These vesicles are food storage organs of the fungus. However, the arbuscules are brush-like dichotomously branched (extensively) haustoria developed within the cortical cells. Mycorrhizal plants have the ability to explore larger soil volume beyond the rhizosphere through the external mycelium that assists in nutrient transport (Jakobsen et. al, 1992; Subramanian and Charest, 1999; Liu et. al, 2000). AMF benefit their host principally by increasing the uptake of relatively immobile 
phosphate ions (Miransari et. al, 2009). Other benefits include: increased uptake of macronutrients, including N, K, and Mg (Veresoglou et. al, 2010), as well as some micronutrients (Kim et. al, 2009) increased resistance to soil pathogens ( Lingua et. al, 2002) increased tolerance to salinity, heavy metals, and drought stress (Li et. al, 2011) regulation of the synthesis and distribution of plant hormones (Barker and Tagu, 2000) and maintenance of soil aggregate stability (Degens et. al, 1996).

Oroxylum indicum is a small or medium sized deciduous tree up to $12-15 \mathrm{~m}$ in height with soft light brown or greyish brown bark with corky lenticels (Dalal and Rai, 2004). O. indicum is being used as a medicinal herb for thousands of years without any known adverse effects (Ahad et. al, 2012). In Indian system of medicine, it has been used as a single drug or as a component of certain poly-herbal drug preparations. O. indicum is an indigenous tree of the Indian subcontinent, distributed throughout the country and is found up to an altitude of $1200 \mathrm{~m}$ mainly along the river banks or slopes of the hills, in damp region and moist places in the forests (Chauhan, 1999; Bennet et. al, 1992). It is distributed in the Himalayan foothills, Eastern and Western Ghats and North East India (Jayaram and Prasad, 2008). It was earlier reported by Pawaar and Kakde (2012) that the root of $O$. indicum does not show any type of mycorrhizal associations at all. However, the present study negates the previous report. It was found that the AM fungi are associated with the rhizosphere of $O$. indicum. The present research deals with the study of association of AM fungi along with the soil nutrient content of O. indicum along different natural habitats in North East India.

\section{MATERIALS AND METHODS}

\section{Collection of the Rhizospheric Soil, Root and Plant Samples}

The rhizospheric soil and plant samples were collected from five different sites of Northeast India, where Oroxylum indicum was naturally growing in its ecological habitat. The rhizospheric soil and root samples and pods were collected from Jorhat, Nalbari, Guwahati, Itanagar and North Lakhimpur. The samples of $O$. indicum were collected from trees showing fruiting from five different collection sites of a single eco-region (Brahmaputra Valley semi- evergreen forests), i. e. Jorhat, Nalbari, Guwahati, Itanagar and North Lakhimpur. The location, GPS coordinates and habitat are mentioned in the Table 1. Rhizospheric soil samples along with root segments were taken by digging out a small amount of soil $(500 \mathrm{~g})$ close to the plant roots up to a depth $15-30 \mathrm{~cm}$ and these samples were kept in sterilized polythene bags for further processing in the laboratory for physicochemical analysis of soil, mycorrhizal colonization and spore quantification etc. In Jorhat the samples were collected from the tree growing along roadside. Rhizospheric samples of the selected plant species were collected from the plant growing along the riverside in Nalbari. From Guwahati, samples were collected from the tree growing in the forest fringe area. Samples from hill slope were collected from Itanagar, while, sample from agricultural farmland were collected from North Lakhimpur. The samples were collected from healthy trees which overall represented the region. Rhizospheric soil samples were collected from mature trees.

\section{Isolation of AM Spores}

The AM spores were isolated by 'Wet sieving and decanting technique' of Gerdemann and Nicolson (Gerdemann and Nicolson, 1963). Approximately $50 \mathrm{~g}$ of soil was added in $500 \mathrm{ml}$ of water in a glass beaker and soil was allowed to settle overnight. The water was decanted through a series of sieves of different sizes $(125 \mu \mathrm{m}, 90 \mu \mathrm{m}, 63 \mu \mathrm{m}$ and $45 \mu \mathrm{m})$ arranged vertically in descending order. The spores trapped in the sieves were repeatedly washed and transferred later to Whatman filter paper No. 1. The spores thus collected were observed under stereo-binocular microscope. The spores were picked by hypodermic needle and then mounted in polyvinyl lactic acid glycerol (PVLG). 
The quantitative estimation of the AM spores was done by Adholeya and Gaur's modified method (Adholeya and Gaur, 1994). The filter paper was divided into many small segments and the total numbers of spores were counted by adding the number of spores present in each segment under stereo-binocular microscope.

\section{Colonization of AM Fungi}

The root colonization was studied by 'Rapid clearing and staining technique (Phillips and Hayman, 1970). The root segments were washed repeatedly under running water. The cleaned roots were cut into small segments of $1 \mathrm{~cm}$ length, and were kept in $10 \% \mathrm{KOH}$ solution for 24 hours at room temperature. $\mathrm{KOH}$ was decanted and root segments were again acidified with $1 \% \mathrm{HCl}$ for 10 minutes. The root segments were stained with $0.5 \%$ trypan blue for 24 hours and then destained with lactophenol. The root segments were then mounted in lactic acid: glycerol (1:1) for observation under microscope.

\section{RESULTS AND DISCUSSIONS}

The rhizospheric samples of Oroxylum indicum were collected from five different collection sites of a single eco-region of Northeast India (Brahmaputra Valley semi- evergreen forests), i. e. Jorhat, Nalbari, Guwahati, Itanagar and North Lakhimpur. In Jorhat the sampling was done along roadside, while, in Nalbari, the sampling was done along the riverside (Table 1). The samples were collected from the forest fringe zone in Guwahati collection site, while, soil samples from hill slope were collected from Itanagar site. In North Lakhimpur site the soil samples were collected from agricultural farmland. GPS coordinates of these sites were recorded. The highest elevation was observed in Itanagar (OI/ ITA/1) while the lowest $(53 \mathrm{msl})$ was found in Nalbari $(\mathrm{OI} / \mathrm{NLB} / 1)$. The maximum soil temperature value $\left(26^{\circ} \mathrm{C}\right)$ was recorded in North Lakhimpur (OI/LKP/1) while minimum soil temperature $\left(19^{\circ} \mathrm{C}\right)$ was observed in Nalbari (OI/ NLB/3). The humidity was found to be highest $(89 \%)$ in Guwahati (OI/GHY/1) and lowest (51\%) in Itanagar (OI/ ITA/1).

Table 1: Survey and GPS Location of Different Collection Sites of Oroxylum Indicum (L.) Benth. ex Kurz

\begin{tabular}{|c|c|c|c|c|c|c|c|}
\hline SITES & Locations & GPS Coordinates & Location & Habitat & Elevation (msl) & Temperature $\left({ }^{\circ} \mathrm{C}\right)$ & Humidity (\%) \\
\hline \multirow{3}{*}{ SITE1 } & OI JRT/1 & $\begin{array}{l}\text { N } 26^{\circ} 47^{\prime} 05.38^{\prime \prime} \\
\text { E } 94^{\circ} 17^{\prime} 15.40^{\prime \prime}\end{array}$ & Jorhat & Roadside & 96 & 21 & 74 \\
\hline & OI JRT/2 & $\begin{array}{l}\text { N } 26^{\circ} 47^{\prime} 15.70^{\prime \prime} \\
\text { E } 94^{\circ} 17^{\prime} 35.97^{\prime \prime}\end{array}$ & Jorhat & Roadside & 99 & 21 & 70 \\
\hline & OI JRT/3 & $\begin{array}{l}\text { N } 26^{\circ} 46^{\prime} 34^{\prime \prime} \\
\text { E } 94^{\circ} 15^{\prime} 34^{\prime \prime}\end{array}$ & Jorhat & Roadside & 97 & 20 & 76 \\
\hline \multirow{3}{*}{ SITE 2} & $\mathrm{OI} / \mathrm{NLB} / 1$ & $\begin{array}{l}\text { N } 26^{\circ} 27^{\prime} 03.49^{\prime \prime} \\
\text { E } 91^{\circ} 27^{\prime} 36.81^{\prime \prime}\end{array}$ & Nalbari & Riverside & 53 & 19 & 61 \\
\hline & $\mathrm{OI} / \mathrm{NLB} / 2$ & $\begin{array}{l}\text { N } 26^{\circ} 27^{\prime} 03.14^{\prime \prime} \\
\text { E } 91^{\circ} 27^{\prime} 36.30^{\prime \prime}\end{array}$ & Nalbari & Riverside & 54 & 20 & 57 \\
\hline & OI NLB/3 & $\begin{array}{l}\text { N } 26^{\circ} 27^{\prime} 03.49^{\prime \prime} \\
\text { E } 91^{\circ} 27^{\prime} 36.81^{\prime \prime}\end{array}$ & Nalbari & Riverside & 53 & 19 & 63 \\
\hline \multirow{3}{*}{ SITE 3} & OI GHY $/ 1$ & $\begin{array}{c}\text { N } 26^{\circ} 05^{\prime} 56^{\prime \prime} \\
\text { E } 91^{\circ} 47^{\prime} 28.57^{\prime \prime} \\
\end{array}$ & Guwahati & Forest fringe & 57 & 23 & 89 \\
\hline & $\mathrm{OI} / \mathrm{GHY} / 2$ & $\begin{array}{l}\text { N } 26^{\circ} 05^{\prime} 52.93^{\prime \prime} \\
\text { E } 91^{\circ} 47^{\prime} 17.49^{\prime \prime}\end{array}$ & Guwahati & Forest fringe & 56 & 22 & 83 \\
\hline & $\mathrm{OI} / \mathrm{GHY} / 3$ & $\begin{array}{l}\text { N } 26^{\circ} 05^{\prime} 48.37^{\prime \prime} \\
\text { E } 91^{\circ} 47^{\prime} 28.06^{\prime \prime}\end{array}$ & Guwahati & Forest fringe & 56 & 23 & 87 \\
\hline \multirow{3}{*}{ SITE 4} & OV/ ITA/1 & $\begin{array}{l}\text { N } 27^{\circ} 05^{\prime} 09.59^{\prime \prime} \\
\text { E } 93^{\circ} 36^{\prime} 27.16^{\prime \prime}\end{array}$ & Itanagar & Hill slope & 783 & 24 & 51 \\
\hline & OI ITA/2 & $\begin{array}{l}\text { N } 27^{\circ} 05^{\prime} 07.09^{\prime \prime} \\
\text { E } 93^{\circ} 36^{\prime} 24.54^{\prime \prime}\end{array}$ & Itanagar & Hill slope & 772 & 24 & 57 \\
\hline & OI ITA/3 & $\begin{array}{l}\text { N } 27^{\circ} 05^{\prime} 07.24^{\prime \prime} \\
\text { E } 93^{\circ} 36^{\prime} 24.26^{\prime \prime}\end{array}$ & Itanagar & Hill slope & 760 & 23 & 55 \\
\hline \multirow{3}{*}{ SITE 5} & OI LKP/1 & $\begin{array}{l}\text { N } 26^{\circ} 57^{\prime} 04.95^{\prime \prime} \\
\text { E } 93^{\circ} 51^{\prime} 32.22^{\prime \prime}\end{array}$ & North Lakhimpur & Paddy field & 98 & 26 & 57 \\
\hline & $\mathrm{OI} / \mathrm{LKP} / 2$ & $\begin{array}{l}\text { N } 26^{\circ} 57^{\prime} 05.63^{\prime \prime} \\
\text { E } 93^{\circ} 51^{\prime} 30.40^{\prime \prime}\end{array}$ & North Lakhimpur & Paddy field & 100 & 24 & 62 \\
\hline & $\mathrm{OI} / \mathrm{LKP} / 3$ & $\begin{array}{l}\text { N } 26^{\circ} 57^{\prime} 08.07^{\prime \prime} \\
\text { E } 93^{\circ} 51^{\prime} 30.19^{\prime \prime}\end{array}$ & North Lakhimpur & Paddy field & 100 & 25 & 59 \\
\hline
\end{tabular}


Table 2 shows the $\mathrm{pH}$ and nutrient status of the soil under naturally growing $O$. indicum tree species. The organic carbon content \%, available Nitrogen (kg/hac), available Potassium and available Phosphorus (P) in kg/hac was determined. The nutrient status of soil varied along different collection sites. The soil status of the sample collected from Jorhat site has a $\mathrm{pH}$ value ranging between $5.89 \pm 0.11$ to $6.2 \pm 0.03$. The soil organic carbon percentage varied between $1.243 \pm 0.034$ to $1.282 \pm 0.025$, available Nitrogen $(\mathrm{kg} / \mathrm{hac})$ ranged between $242.69 \pm 0.001$ to $301.27 \pm 0.001$, and available Phosphorus $(\mathrm{kg} / \mathrm{hac})$ varied between $34.39 \pm 2.90$ to $39 \pm 3.151$, while available potassium $(\mathrm{kg} / \mathrm{hac})$ varied between $28.52 \pm 0.754$ to $37.36 \pm 1.24$. In Nalbari site the $\mathrm{pH}$ of the soil varied from $5.91 \pm 0.11$ to $6.11 \pm 0.08$. The organic carbon percentage was found to range between $1.320 \pm 0.033$ to $1.397 \pm 0.034$, the available nitrogen $(\mathrm{kg} / \mathrm{hac}) \mathrm{varied}$ between $326.37 \pm 0.002$ to $359.85 \pm 0.002$; available phosphorus ( $\mathrm{kg} / \mathrm{hac}$ ) was between $40.78 \pm 3.15$ to $43.61 \pm 0.81$ and available

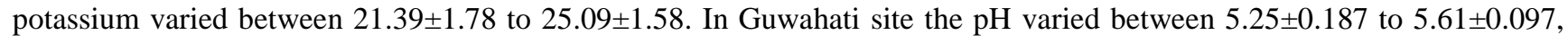
the organic carbon ranged between $1.760 \pm 0.050$ to $1.808 \pm 0.033$. The available nitrogen $(\mathrm{kg} / \mathrm{hac}) \mathrm{varied}$ between $175.74 \pm 0.0006$ to $217.58 \pm 0.001$; available phosphorus $(\mathrm{kg} / \mathrm{hac})$ was between $38.82 \pm 0.614$ to $41.8 \pm 0.063$ and available potassium varied between $29.37 \pm 1.24$ to $36.22 \pm 1.02$. The soil nutrient status of Itanagar site shows that the pH varied between $5.17 \pm 0.323$ to $5.47 \pm 0.279$, The organic carbon percentage was found to be $1.081 \pm 0.078$, the available nitrogen $(\mathrm{kg} / \mathrm{hac})$ varied between $472.82 \pm 0.001$ to $564.88 \pm 0.001$, available phosphorus $(\mathrm{kg} / \mathrm{hac})$ was between $44.32 \pm 1.799$ to $46.27 \pm 0.307$ and available potassium varied between $42.49 \pm 1.50$ to $45.34 \pm 1.48$. In North Lakhimpur site the $\mathrm{pH}$ of the soil varied from $5.38 \pm 0.43$ to $6.05 \pm 0.131$. The organic carbon percentage was found to range between $1.808 \pm 0.033$ to $1.865 \pm 0.049$, the available nitrogen $(\mathrm{kg} / \mathrm{hac})$ varied between $594.17 \pm 0.003$ to $648.56 \pm 0.004$, available phosphorus $(\mathrm{kg} / \mathrm{hac})$ was between $48.22 \pm 0.639$ to $50.17 \pm 0.639$ and available potassium varied between $45.06 \pm 1.99$ to $49.34 \pm 1.50$. (Figure $1 \mathrm{~A}$ )

Table 2: Soil Status of Different Collection Sites of Oroxylum Indicum (L.) Benth. ex Kurz

\begin{tabular}{|c|c|c|c|c|c|}
\hline Sample & $\mathrm{pH}$ & $\% 0 \mathrm{C}$ & Available $\mathrm{N}(\mathrm{kg} / \mathrm{hac})$ & Avl P (kg/hac) & Avl K (kg/hac) \\
\hline 0I/JRT/1 & $5.89 \pm 0.11$ & $1.282 \pm 0.025$ & $242.69 \pm 0.001$ & $39 \pm 3.151$ & $36.506 \pm 1.73$ \\
\hline 0I/JRT/2 & $6.2 \pm 0.03$ & $1.243 \pm 0.034$ & $251.05 \pm 0.002$ & $34.39 \pm 2.90$ & $28.52 \pm 0.754$ \\
\hline 0I/JRT/3 & $5.74 \pm 0.141$ & $1.253 \pm 0.025$ & $301.27 \pm 0.001$ & $34.75 \pm 5.22$ & $37.36 \pm 1.24$ \\
\hline OI/NLB/1 & $6 \pm 0.173$ & $1.339 \pm 0.025$ & $330.56 \pm 0.001$ & $40.78 \pm 3.15$ & $21.39 \pm 1.78$ \\
\hline $0 \mathrm{I} / \mathrm{NLB} / 2$ & $6.11 \pm 0.08$ & $1.397 \pm 0.034$ & $326.37 \pm 0.002$ & $41.48 \pm 1.91$ & $24.81 \pm 1.30$ \\
\hline $0 \mathrm{I} / \mathrm{NLB} / 3$ & $5.91 \pm 0.11$ & $1.320 \pm 0.033$ & $359.85 \pm 0.002$ & $43.61 \pm 0.81$ & $25.09 \pm 1.58$ \\
\hline $0 \mathrm{I} / \mathrm{GHY} / 1$ & $5.4 \pm 0.221$ & $1.760 \pm 0.050$ & $209.21 \pm 0.008$ & $41.8 \pm 0.063$ & $36.22 \pm 1.02$ \\
\hline $0 \mathrm{I} / \mathrm{GHY} / 2$ & $5.25 \pm 0.187$ & $1.760 \pm 0.074$ & $175.74 \pm 0.006$ & $39.71 \pm 0.987$ & $29.37 \pm 1.24$ \\
\hline $0 \mathrm{I} / \mathrm{GHY} / 3$ & $5.61 \pm 0.097$ & $1.808 \pm 0.033$ & $217.58 \pm 0.001$ & $38.82 \pm 0.614$ & $34.79 \pm 1.99$ \\
\hline 0I/TA/1 & $5.41 \pm 0.270$ & $1.081 \pm 0.050$ & $472.82 \pm 0.001$ & $45.92 \pm 0.639$ & $43.92 \pm 1.73$ \\
\hline $0 \mathrm{I} / \mathrm{TTA} / 2$ & $5.47 \pm 0.279$ & $1.081 \pm 0.078$ & $502.11 \pm 0.001$ & $44.32 \pm 1.799$ & $45.34 \pm 1.48$ \\
\hline 0I/ITA/3 & $5.17 \pm 0.323$ & $1.081 \pm 0.058$ & $564.88 \pm 0.001$ & $46.27 \pm 0.307$ & $42.49 \pm 1.50$ \\
\hline 0I/LKP/1 & $5.65 \pm 0.174$ & $1.808 \pm 0.033$ & $594.17 \pm 0.003$ & $48.22 \pm 0.639$ & $49.34 \pm 1.50$ \\
\hline $0 \mathrm{I} / \mathrm{LK} / 2$ & $6.05 \pm 0.131$ & $1.846 \pm 0.041$ & $648.56 \pm 0.004$ & $50.17 \pm 0.639$ & $45.63 \pm 0.75$ \\
\hline $0 \mathrm{I} / \mathrm{LK} / 3$ & $5.38 \pm 0.43$ & $1.865 \pm 0.049$ & $623.46 \pm 0.001$ & $48.58 \pm 0.639$ & $45.06 \pm 1.99$ \\
\hline
\end{tabular}



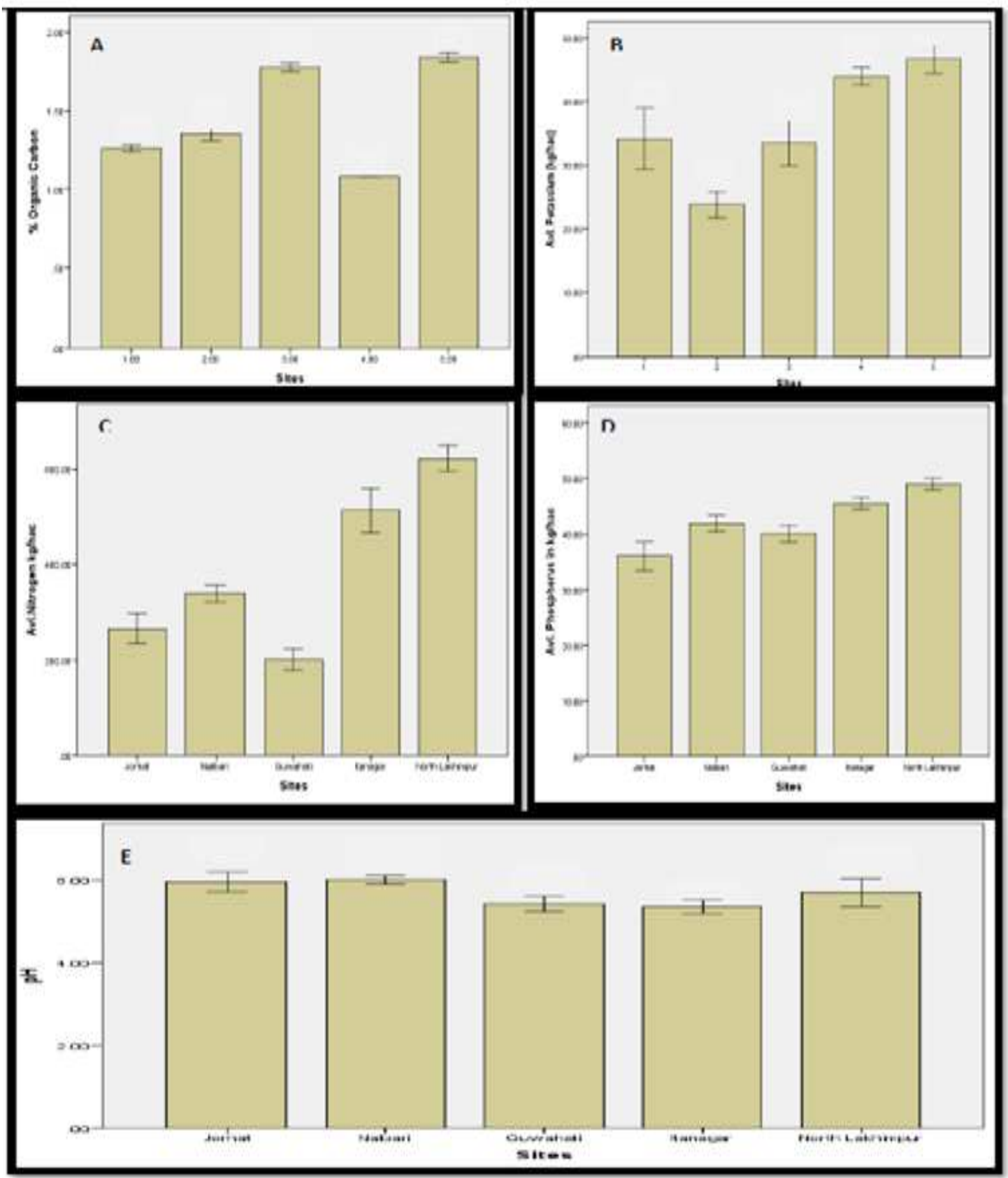

Plate 1 A: DMRT analysis of soil status of different sites

\section{A: Organic Carbon \% in different sites}

B: Available Potassium in $\mathrm{kg} / \mathrm{hac}$ in different sites

C: Available Nitrogen $\%$ in $\mathrm{kg} / \mathrm{hac}$ in different sites

D: Available Phosphorus in $\mathrm{kg} / \mathrm{hac}$ in different sites

$\mathrm{E}$ : $\mathrm{pH}$ of soil in different sites

Figure 1(a) 
Table 3 shows the AM spore quantification and root colonization of rhizospheric soil samples of $O$. indicum of different sites. The maximum (311.33 44.97$)$ AM spore count per $50 \mathrm{gm}$ of soil, number was observed in the North Lakhimpur (OI/LKP/1) sample while minimum number $(91.33 \pm 10.93)$ was reported in Itanagar (OI/ITA/1) sample. Three types of root infection/ colonization was present in roots of $O$. indicum $i$. $e$. hyphal, arbuscular and vesicular colonization. The range of hyphal colonization in roots was from $53.33 \pm 3.33$ in Nalbari (OI/NLB/2) to $100 \pm 0$ in North Lakhimpur (OI/LKP/3) samples respectively. The observed arbuscular colonization ranged from $10 \pm 0$ in Nalbari $(\mathrm{OI} / \mathrm{NLB} / 3)$ to $40 \pm 5.77$ and $40 \pm 10.00$ in North Lakhimpur (OI/LKP/1) and OI/LKP/3 sites respectively. Vesicular colonization was maximum $(56.66 \pm 8.81)$ in North Lakhimpur (OI/LKP/3) site minimum (6.66 \pm 3.33$)$ in Nalbari (OI/NLB/1 and OI/NLB/3) and Itanagar (OI/ITA/1) site. The analysis of the data revealed that the root colonization was positively correlated with the soil nutrient status of the samples collected from various collection sites. The correlation value of 0.766 was obtained when root colonization was compared with soil organic carbon percentage. The root colonization and soil nitrogen content also had positive correlation value of 0.413 . Similarly the available phosphorus and potassium in the soil was positively correlated with root colonization, with correlation values of 0.387 and 0.567 respectively. The root colonization was found to be negatively correlated with soil ph. (Figure 1B).

Table 3: Spore Count and Root Colonization of Oroxylum Indicum (L.)

Benth. ex Kurz Collected from Different Sites

\begin{tabular}{|l|c|c|c|c|}
\hline \multicolumn{1}{|c|}{ Sample } & Spore Count & $\begin{array}{c}\text { Hyphal } \\
\text { Colonization \% }\end{array}$ & $\begin{array}{c}\text { Arbuscular } \\
\text { Colonization \% }\end{array}$ & $\begin{array}{c}\text { Vescicular } \\
\text { Colonization \% }\end{array}$ \\
\hline OI/JRT/1 & $161.33 \pm 7.68$ & $63.33 \pm 5.19$ & $20 \pm 3.98$ & $16.66 \pm 3.98$ \\
\hline OI/JRT/2 & $173.66 \pm 5.84$ & $70 \pm 5.77$ & $20 \pm 0$ & $23.33 \pm 3.33$ \\
\hline OI/JRT/3 & $159 \pm 3.055$ & $73.33 \pm 3.33$ & $30 \pm 5.77$ & $30 \pm 5.77$ \\
\hline OI/NLB/1 & $131 \pm 3.78$ & $60 \pm 4.36$ & $16.66 \pm 6.41$ & $6.66 \pm 3.33$ \\
\hline OI/NLB/2 & $103.33 \pm 5.78$ & $53.33 \pm 3.33$ & $13.33 \pm 3.33$ & $16.66 \pm 3.33$ \\
\hline OI/NLB/3 & $105.33 \pm 4.17$ & $56.66 \pm 8.81$ & $10 \pm 0$ & $6.66 \pm 3.33$ \\
\hline OI/GHY/1 & $252.85 \pm 6.85$ & $73.33 \pm 3.33$ & $23.33 \pm 3.33$ & $26.66 \pm 3.33$ \\
\hline OI/GHY/2 & $260.33 \pm 4.37$ & $83.33 \pm 3.33$ & $30 \pm 5.77$ & $40 \pm 5.77$ \\
\hline OI/GHY/3 & $256.66 \pm 2.02$ & $80 \pm 5.77$ & $36.66 \pm 3.33$ & $43.33 \pm 6.66$ \\
\hline OI/TA/1 & $91.33 \pm 10.93$ & $56.66 \pm 3.33$ & $20 \pm 5.77$ & $6.66 \pm 3.33$ \\
\hline OI/TA/2 & $109.33 \pm 5.23$ & $63.33 \pm 3.33$ & $13.33 \pm 3.33$ & $16.66 \pm 3.33$ \\
\hline OI/TA/3 & $93.33 \pm 4.37$ & $73.33 \pm 3.33$ & $13.33 \pm 6.66$ & $13.33 \pm 6.66$ \\
\hline OILKP/1 & $231 \pm 1.52$ & $96.66 \pm 3.33$ & $40 \pm 5.77$ & $53.33 \pm 6.66$ \\
\hline OILKP/2 & $286.33 \pm 4.63$ & $90 \pm 5.77$ & $40 \pm 0$ & $43.33 \pm 8.81$ \\
\hline OILKP/3 & $311.33 \pm 4.97$ & $100 \pm 0$ & $40 \pm 10.00$ & $56.66 \pm 8.81$ \\
\hline
\end{tabular}




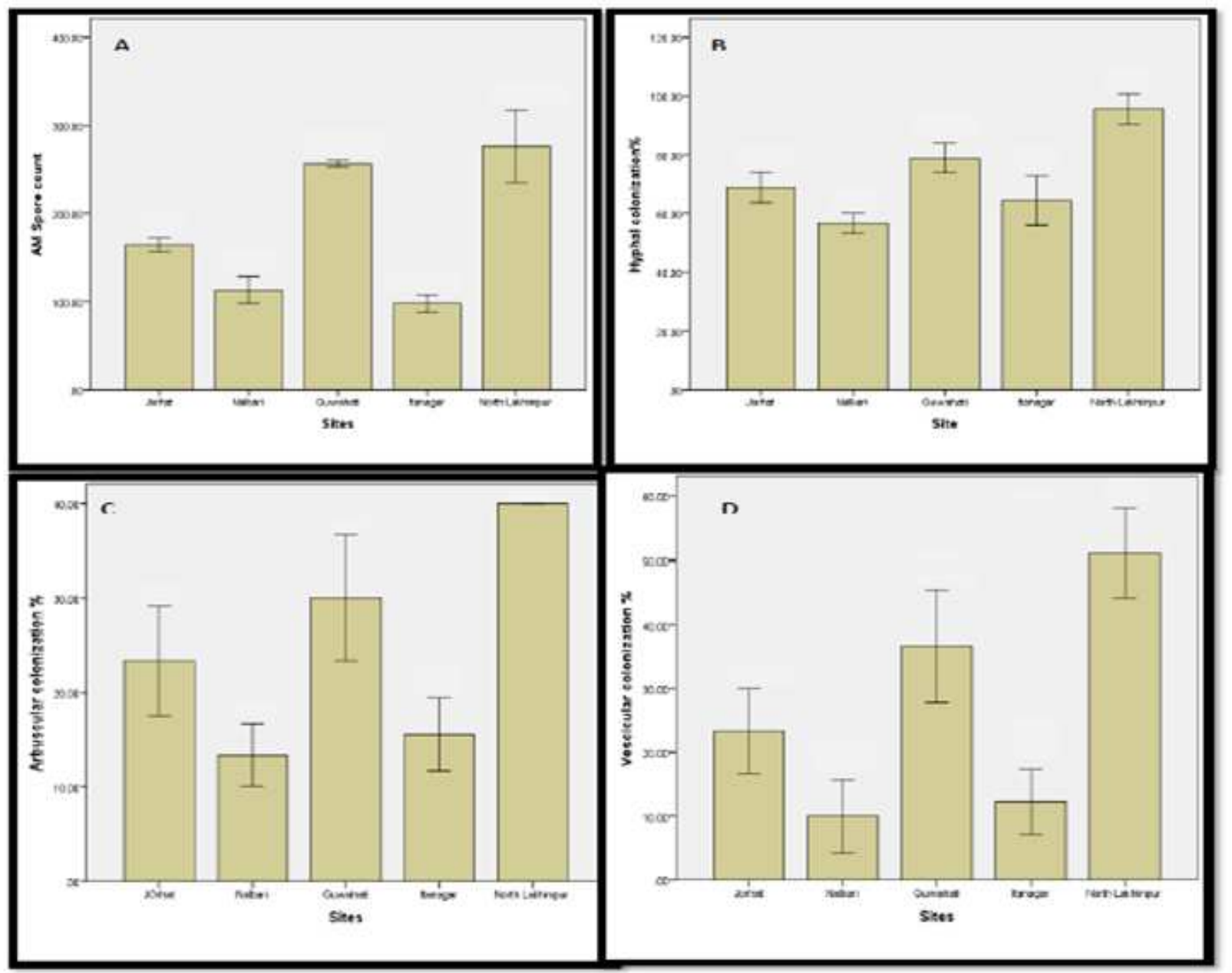

Plate 1 B: DMRT analysis of AM Spore count and Root colonization of

A: AM Spore count in different sites different sites

B: Hyphal colonization $\%$ in different sites

C: Arbuscular colonization $\%$ in different sites

D: Vescicular colonization $\%$ in different sites

Figure 1(b)

The DMRT analysis of different parameters was done to segregate differentvariables ( $\leq 0$. 05). The DMRT analysis of the pH status was higher in Jorhat and Nalbari, intermediate pH was found in North Lakhimpur site while mimum $\mathrm{pH}$ was found in Guwahati and Itanagar site. Overall, the $\mathrm{pH}$ of the soil under $O$. indicum is acidic. The \% Organic Carbon was found to be highest in North Lakhimpur site while it was lowest in Itanagar site. Available Nitrogen was highest in NorthLakhimpur, while it was minimum in Guwahati. Available Phosphorus was again the highest in North Lakhimpur site while it was lowest in Nalbari and Guwahati site. Available Potassium was highest in Itanagar and North Lakhimpur sites while it was lowest in Nalbari site. The DMRT analysis of the AM spore count shows that North Lakhimpur and Guwahati sites have highest AM spore count while, Itanagar and Nalbari sites have minimum AM spore count. The hyphal colonization \% was maximum in North Lakhimpur site and minimum in Nalbari site. The Arbuscular colonization \% was again maximum in North Lakhimpur site and minimum in Nalbari site while, the Vescicular colonization \% was maximum in North Lakhimpur and Guwahati sites while it was minimum in Itanagar and Nalbari sites(Table 4). 
Table 4: DMRT analysis of Soil Status and AM Spore Count, Hyphal Colonization \%, Arbuscular Colonization \% and Vescicular Colonization \% of Different Sites

\begin{tabular}{|c|c|c|c|c|c|}
\hline \multirow{2}{*}{ Attributes } & \multicolumn{5}{|c|}{ Sites } \\
\hline & Jolhat(1) & Nalbari(2) & Guwahati(3) & Itanagar(4) & North Laklimpulr(5) \\
\hline $\mathrm{pH}$ & $5.9433^{\mathrm{a}}$ & $6.0067^{\mathrm{a}}$ & $5.420^{b}$ & $5.350^{b}$ & $5.693^{3 \mathrm{ab}}$ \\
\hline$\% 0 \mathrm{C}$ & $1.2593^{\mathrm{d}}$ & $1.3520^{c}$ & $1.7760^{b}$ & $1.081^{\mathrm{e}}$ & $1.8397^{\mathrm{a}}$ \\
\hline Available N (kg/hac) & $265.00^{d}$ & $338.926^{\circ}$ & $200.84^{e}$ & $513.27^{b}$ & $622.06^{\mathrm{a}}$ \\
\hline AvlP (kg/hac) & $36.0467^{d}$ & $41.9567^{c}$ & $40.1100^{\circ}$ & $45.503^{b}$ & $48.99^{\mathrm{a}}$ \\
\hline Avl K (kg/hac) & $34.1287^{\circ}$ & $23.7633^{\mathrm{C}}$ & $33.4600^{b}$ & $43.916^{\mathrm{a}}$ & $46.6767^{2}$ \\
\hline Spore count & $164.663^{b}$ & $113.2200^{\circ}$ & $256.613^{2}$ & $97.99^{c}$ & $276.220^{2}$ \\
\hline Hyphal colonization \% & $68.88 b^{\circ}$ & $56.66^{d}$ & $78.886^{b}$ & $64.44^{\text {cd }}$ & $95.553^{\mathrm{a}}$ \\
\hline Arbuscular colonization \% & $23.33^{b c}$ & $13.330^{d}$ & $29.996^{b}$ & $15.553^{\text {cd }}$ & $40.00^{2}$ \\
\hline Vescicular colonization \% & $164.663^{b}$ & $113.220^{c}$ & $256.613^{\mathrm{a}}$ & $97.996^{\circ}$ & $276.220^{\mathrm{a}}$ \\
\hline
\end{tabular}

\section{Arbuscular Mycorrhizal (AM) Spore Diversity Associated with the Rhizospheric Soil Samples of Oroxylum Indicum (L.) Benth. ex Kurz}

The AM diversity of all the rhizospheric soil samples was assessed. The study revealed that a total of 23 species of AM fungi belonging to 5 genera (i. e. Glomus, Gigaspora, Acaulospora, Entrophospora, Pacispora) were isolated from the rhizospheric soil of $O$. indicum as mentioned in Table 5. Glomus was found to be maximum in the rhizosphere of O. indicum, followed by Acaulospora and Gigaspora sp., Pacispora sp and Entrophospora sp. AM spores in Jorhat site comprised of Acaulospora spinosa, Glomus geosporum, Acaulospora mellea, Gigaspora sp., Acaulospora rehmii, Entrophospora sp. AM spores in Nalbari constituted of Gigaspora decipience, Glomus sp., Acaulospora scrobiculata, Glomus palladium, Glomus geosporum. AM spores in Guwahati Gigaspora gigantea, Glomus geosporum, Acaulospora laevis, Glomus macrocarpum, Glomus mosseae, Gigaspora sp., Glomus microcarpum, Glomus sp., Acaulospora sp. AM spores in Itanagar comprised of Glomus fasciculatum, Glomus clarum, Gigaspora nigra, Glomus mosseae, Acaulospora bireticulata, Glomus geosporum. AM spores in North Lakhimpur site comprised Glomus mosseae, Acaulospora sp., Pacispora sp, Glomus multicaule, Glomus geosporum, Glomus aggregatum, Acaulospora leavis only (Figure 2). 
Table 5: AM Spore Diversity Associated with Oroxylum Indicum (L.) Benth. ex Kurz

\begin{tabular}{|c|c|c|c|c|c|c|}
\hline SLLNO. & All Species & Jorhat & Nalbari & Guwrahati & Itanggar & N. Lakhimpul \\
\hline 1. & Acaulospora scrobiculata Trappe & . & + & . & . & . \\
\hline 2. & Acaulospora sp. & . & . & + & . & + \\
\hline 3. & Accullospora laevis Gerdemann and Trappe & . & . & + & & + \\
\hline 4. & Acaulospora bireticulata (Rothwell and Trappe) & . & . & . & + & . \\
\hline 5. & Acaulospora mellea ( Spain and Schenck) & + & $\cdot$ & . & $\cdot$ & $\cdot$ \\
\hline 6. & Accullospora rehmil(Sieverd, and S.Toro) & + & . & . & . & . \\
\hline 7. & Accullospora spinosa (Walker and Trappe) & + & . & . & $\cdot$ & $\cdot$ \\
\hline 8. & Entrophospora sp. & + & . & $\cdot$ & $\cdot$ & $\cdot$ \\
\hline 9. & Gigaspora giguntea (Nicol. and Gerd.) Gerd. and Trappe & $\cdot$ & $\cdot$ & + & $\cdot$ & $\cdot$ \\
\hline 10. & Giguspora decipience (Hall and Abbott) & - & + & - & $\cdot$ & $\cdot$ \\
\hline 11. & Gigaspora nigra (J.F. Rechead) & $\cdot$ & . & - & + & $\cdot$ \\
\hline 12 & Giguspora. sp. & + & $\cdot$ & + & $\cdot$ & $\cdot$ \\
\hline 13. & Glomus aggregatum (Schenck and Smith emend. Koske) & - & . & - & . & + \\
\hline 14 & Glomus fasciculatum (Thaxter sensu Gerd.) Gerd, and Trappe) & . & . & - & + & . \\
\hline 15. & Glomus geosportum (Nicol. and Gerd.) Wallker & + & + & + & + & + \\
\hline 16. & Glomus macroccurpum Tulasne and Tulassne & - & - & + & . & - \\
\hline 17. & Glomus mossece (Nicol. and Gerd.). Gerd, \& Trappe & - & - & + & + & + \\
\hline 18. & Glomus multicaule Gerd, and Baskhi & - & - & - & - & + \\
\hline 19. & Glomus palladicum Hall & . & $t$ & . &. & - \\
\hline 20. & Glomus sp, Tulassne and Tulassne & - & + & + & - & - \\
\hline 21. & Glomus clarum (Nicolson and Schendk) & - & - & - & + & - \\
\hline 22. & Glomus microcarpum (Tul. and C. Tul.) & - & - & + & - & - \\
\hline 23. & Pacispora sp. & . & . & - & . & t \\
\hline
\end{tabular}

+ denotes present, - denotes absent 

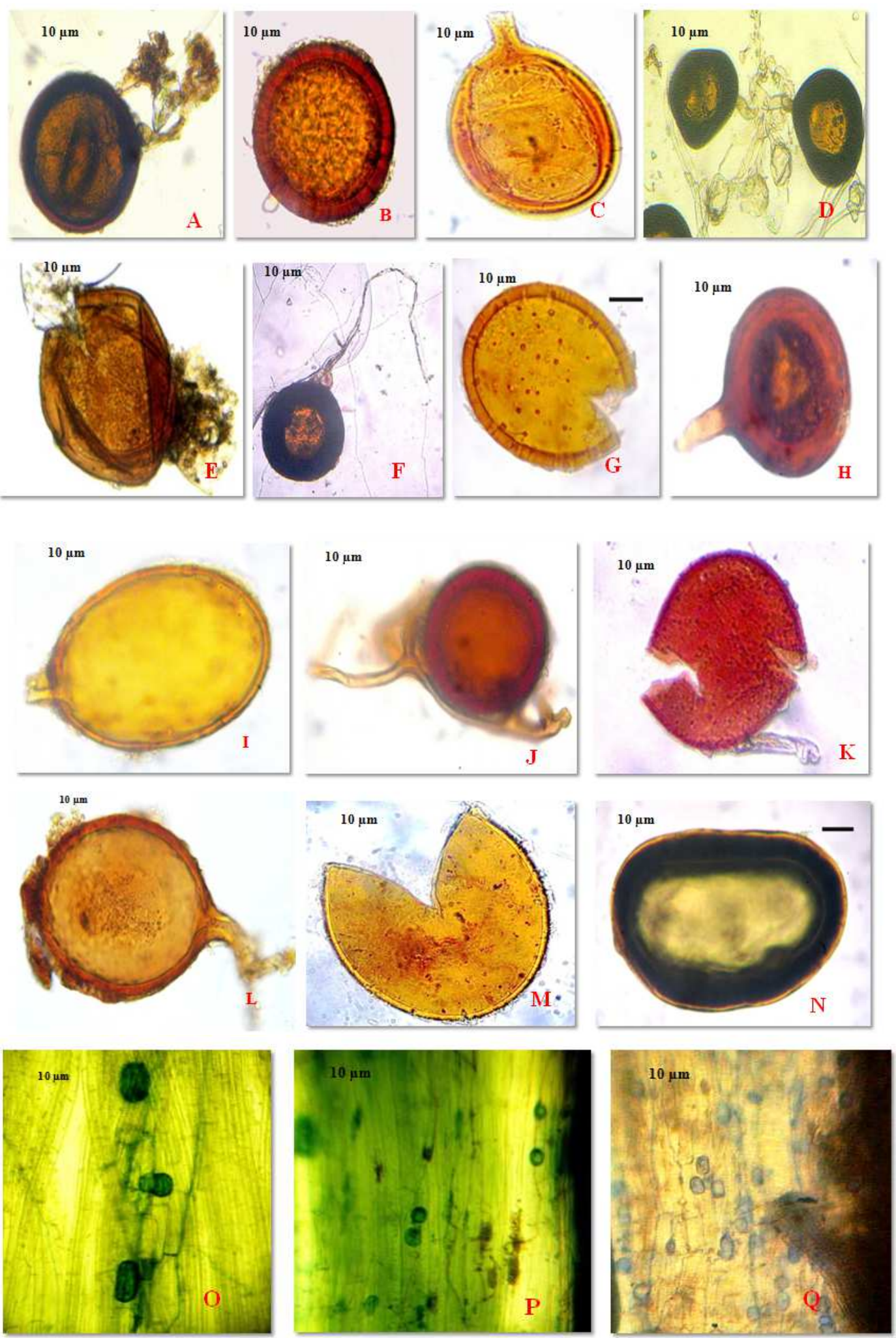

Figure 2 (A): Gigaspora Decipience, (B): Acaulospora Bireticulata

(C): Glomus fasciculatum (D): Glomus aggregatum (E): Acaulospora spinosa

(F): Gigaspora nigra, (G): Acaulospora sp (H): Glomus Microcarpum

$(\mathrm{J})$ : Glomus multicaule (K): Glomus sp. (L): Glomus mosseae

(M): Glomus geosporum (N): Entrophospora sp

(O-Q): Network of hyphae, vescicles and arbuscules inside root of O.indicum 
Oroxylum Indicum (L.) Benth Ex Kurz Growing under

Different Natural Habitat in Northeast India

Spore Morphology of AM Spores

The spore morphology of various AM spores is shown in Table 6. The identification was done on the basis of morphological characteristictics. The micrometry of the spores was done to determine the size of the spores. The spore characteristics are mentioned below

Table 6: Spore Morphology of AM Fungi Associated with O. Indicum

\begin{tabular}{|c|c|c|c|c|c|c|c|}
\hline SLINOH, & AlISpecies & $\begin{array}{l}\text { Spore size } \\
(\mu \mathrm{m}) \\
\end{array}$ & Sporeshape & Spore colour & Wall layers & Omamentation & $\begin{array}{l}\text { Subtending } \\
\text { hyphare }\end{array}$ \\
\hline 1. & $\begin{array}{l}\text { Acaulospora } \\
\text { spinosa }\end{array}$ & $300 \times 250$ & Sub globoseto globose & Ditty brown to brown & Twowall layers & $\begin{array}{l}\text { Surface omamented with } \\
\text { blumtedspines }\end{array}$ & Absent \\
\hline 2. & Acaulosporamellea & $130 \times 110$ & Sub globosesto oroid & Reddish Brornato brown & Threetrall layers & $\begin{array}{l}\text { Concarepits present on } \\
\text { payillaze }\end{array}$ & Absent \\
\hline 3. & Acaulosporarehmii & $110 \times 120$ & Round & Paleroornto dark brown & Wall layer not distumct & $\begin{array}{l}\text { Labyinth form of chamels } \\
\text { on wadl layer }\end{array}$ & Absent \\
\hline 4. & Acaulosporasp. & $130 \times 130$ & Globosettosub globose & 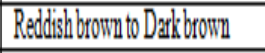 & Smoothwall laver & Presenceof oncareve pits & Present \\
\hline$j$. & Acaulosporalavis & $300 \times 300$ & Ellipsoidt sub ellipsoid & Yellowish brown to hooney brorn & Smooth wall laver & Smoothsurface & Absent \\
\hline 6. & $\begin{array}{l}\text { Acaulospora } \\
\text { bireticulata }\end{array}$ & $90 \times 90$ & Globoset to sub globose & Daul gereyshb brown to brown & Threetrall layers & $\begin{array}{l}\text { Polygound reticulum netroots } \\
\text { on surface } \\
\end{array}$ & Present \\
\hline 7. & $\begin{array}{l}\text { Acaulospora } \\
\text { scrobiculata }\end{array}$ & $400 \times 370$ & Globoseto sub globose & Brown to Dall brorn & Unitwall layer & $\begin{array}{l}\text { Timymulfiple Concave pits } \\
\text { oversurface }\end{array}$ & Absent \\
\hline 8. & Glomus macrocoppum & $150 \times 150$ & $\begin{array}{l}\text { Globoseto sub globoseto } \\
\text { oroid }\end{array}$ & Dall bromp & Nultiple layered & $\begin{array}{l}\text { Cross chamels present on } \\
\text { walls }\end{array}$ & Absent \\
\hline 9. & Glomus palladium & $200 \times 200$ & Globoseto sub globose & Lightyellowish brown & Twortall layer & Sporocarp contain peridium & Absent \\
\hline 10. & Glomus microcarpum & $70 \times 100$ & $\begin{array}{l}\text { Globoseto sub globoseto } \\
\text { ellinsoid }\end{array}$ & Dalkyellowish brown to brorn & Onervall with trolayers & Smooth withlaminations & Present \\
\hline 11. & Glomus aggregatum & $\begin{array}{c}130 \times 130 \\
\text { (Size of each } \\
\text { zygosporese) }\end{array}$ & Globoset to Subglobosett orvoid & Ditryellowish brorn to brown & $\begin{array}{l}\text { Onervall with theee } \\
\text { lagers }\end{array}$ & Lamimated wall layer & $\begin{array}{l}\text { Present } \\
\text { ageregegted }\end{array}$ \\
\hline 12. & Glomus sp. & $150 \times 150$ & Globoset to sub globose & $\begin{array}{l}\text { Yellowish brown to brownish } \\
\text { yellow }\end{array}$ & Smalerwall layer & Sporocarppresent with wats & Absent \\
\hline 13. & Glomus geosportun & $170 \times 150$ & Globoseto sub globose & Yellowishhoney broorn & Threetrall lavers & Smooth & Absent \\
\hline 14. & Glomus fasciculatum & $100 \times 100$ & Globoset to sub globose & Yellorishbrorornto brown & Threetrall layers & $\begin{array}{l}\text { Pefforted with thickened } \\
\text { imrardprojections }\end{array}$ & Absent \\
\hline 15. & Glomus clarum & $180 \times 1.40$ & Globoseto Sub globose & Hyalmeto pale yellow colour & $\begin{array}{l}\text { Singleviall with truee } \\
\text { layers }\end{array}$ & Laminated spore wall & Absent \\
\hline 16. & Glomus multicaule & $150 \times 150$ & $\begin{array}{l}\text { Globoset to sub globose to } \\
\text { oroid }\end{array}$ & Dasil bromn to brown & Simgle thick wall layer & Very tick omamention & $\begin{array}{l}\text { Nultiple } \\
\text { attached hyphase }\end{array}$ \\
\hline 17. & Glomus mosseal & $100 \times 150$ & Globoset to Sub globose & Honey brorry to yellowish brown & Smalevill laver & Hyalmeouter wall & Absent \\
\hline 18. & Gigasporasp. & $450 \times 500$ & Sub globoset to oroid & Dityyellowish brorn to brorn & Simdervall layer & Presence of tratsitsegeglay & Absent \\
\hline 19. & Gigaspora nigra & $550 \times 550$ & Globoseto sub globose & $\begin{array}{l}\text { Dittyellowish.brornato Dall } \\
\text { brown }\end{array}$ & Smglervall layer & Irregular wath & Present \\
\hline 20. & Gigaspora gigantea & $750 \times 750$ & Globosettos subglobose & Yellowishbroronto brorn & Doublewwall layer & $\begin{array}{l}\text { Omamented with erevely } \\
\text { distributed wath }\end{array}$ & Absent \\
\hline 21. & Gigaspora decipience & $300 \times 300$ & Globoseto subglobose & Paleyellow to brownishy yellow & Three layered wiall & Warty & Present \\
\hline 22. & Entophhosporasp. & $300 \times 100$ & Flattened dlipsoid & Yellowish brorn & $\begin{array}{l}\text { Simglewall with multiple } \\
\text { lager }\end{array}$ & Hyalime & Absent \\
\hline 23. & $\begin{array}{l}\text { Pacispora sp. } \\
\text { (carapazese) }\end{array}$ & $130 \times 100$ & $\begin{array}{l}\text { Globoset osub globoseto } \\
\text { oroid }\end{array}$ & $\begin{array}{l}\text { Ditty Yellowish bromtonto } \\
\text { Yellowish brovn }\end{array}$ & Smaglervall layer & Presence of rwats irregglar & Absent \\
\hline
\end{tabular}




\section{Acaulospora Scrobiculata (Trappe)}

The spore size varies between $400 \times 370(\mu \mathrm{m})$. The spore shape is sub globose to globose. The colour of the spore is brown to dark brown. The spore has a single wall layer with surface ornamented with tiny multiple concave pits.

\section{Acaulospora Spinosa (Walker and Trappe)}

The spore size ranges between $300 \times 250(\mu \mathrm{m})$. The spore shape is sub globose to globose. The colour of the spore is dirty brown to brown. The spore has two wall layers with surface ornamented with blunted spines.

\section{Acaulospora Mellea (Spain and Schenck)}

The spore size ranges between $130 \times 110(\mu \mathrm{m})$. The spore shape is sub globose to ovoid. The colour of the spore is reddish brown to brown. The spore has three wall layers with concave pits present on papillae

Acaulospora Rehmii (Sieverd. and S. Toro)

The spore size ranges between $110 \times 120(\mu \mathrm{m})$. Round spore shape. The colour of the spore is pale brown to dark brown. The wall layer is not distinct. The surface is ornamented with a labyrinth form of channels on wall layers.

\section{Acaulospora sp.}

The spore size ranges between $130 \times 130(\mu \mathrm{m})$. The spore shape is globose to sub globose. The colour of the spore is reddish brown to dark brown. The spore has smooth wall layers with the presence of concave pits. Subtending hypha is present.

\section{Acaulospora Laevis (Gerdemann and Trappe)}

The spore size ranges between $300 \times 300(\mu \mathrm{m})$. The spore shape is ellipsoid to sub ellipsoid. The colour of the spore is yellowish-brown to honey brown. The spore has a smooth wall layer with smooth surface.

\section{Acaulospora Bireticulata (Rothwell and Trappe)}

The spore size ranges between $400 \times 370(\mu \mathrm{m})$. The spore shape varies between globose to sub globose. The colour of the spore is brown to dark brown. The spore has unit wall layer with ornamented with tiny multiple concave pits. Subtending hypha is present.

\section{Glomus Macrocarpum (Tulasne and Tulasne)}

The spore size ranges between $150 \times 150(\mu \mathrm{m})$. The spore shape varies between globose to sub globose to ovoid. The spore is dark brown in colour. Multiple layered spore wall with cross channels present on walls.

\section{Glomus Palladium (Hall)}

The size of the spore is between $200 \times 200(\mu \mathrm{m})$. The spore shape varies between globose to sub globose. The colour of the spore is light yellowish brown. It has two wall layers with sporocarp containing peridium.

\section{Glomus Macrocarpum (Tul. and C. Tul.)}

The size of the spore is between $70 \times 100(\mu \mathrm{m})$. The spore shape varies between globose to sub globose to ellipsoid. The colour of the spore varies from dark yellowish brown to brown. The single wall layer is present with two layers. The surface of the wall is smooth with laminations. Subtending hypha is present. 
The size of each zygospore is between $130 \times 130(\mu \mathrm{m})$ which are aggregated together. The spore shape varies between globose to sub globose to ovoid. The colour of the spore varies from dirty yellowish brown to brown. The spore has single wall with three layers. The spore wall is laminated. There is presence of aggregated hyphae.

\section{Glomus sp.}

The size of the spore is between $150 \times 150(\mu \mathrm{m})$. The spore shape varies between sub globose to globose. The colour of the spore varies from yellowish brown to brownish yellow. There is the presence of a single wall layer, with sporocarp present with warts.

\section{Glomus Geosporum (Nicol. and Gerd.) Walker}

The size of the spore is between $170 \times 150(\mu \mathrm{m})$. The spore shape varies between sub globose to globose. The colour of the spore is yellowish honey brown. The surface is smooth with three wall layers.

\section{Glomus Fasciculatum (Thaxter sensu Gerd.) Gerd. and Trappe}

The size of the spore is between $100 \times 100(\mu \mathrm{m})$. The spore shape varies between globose to sub globose. The colour of the spore is yellowish brown to brown. Three wall layers with surface perforated with thickened inward projections.

\section{Glomus Clarum (Nicolson and Schenck)}

The size of the spore is between $180 \times 140(\mu \mathrm{m})$. The spore shape varies between globose to sub globose. The colour of the spore varies from hyaline to pale yellow colour. There is single wall with three wall layers. The spore wall is laminated.

\section{Glomus Multicaule (Gerd. and Baskhi)}

The size of the spore is between $150 \times 150(\mu \mathrm{m})$. The spore shape varies between globose to sub globose to ovoid. The colour of the spore varies from dark brown to brown. Presence of single thick wall layer with very thick ornamentation. Multiple attached hyphae are present.

\section{Glomus Mosseae (Nicol. and Gerd.) Gerd. and Trappe}

The size of the spore is between $100 \times 150(\mu \mathrm{m})$. The spore shape varies between globose to sub globose. The colour of the spore varies from honey brown to yellowish brown. Presence of single wall layer. The wall layer is hyaline.

\section{Gigaspora Sp.}

The size of the spore is between $450 \times 500(\mu \mathrm{m})$. The spore shape varies between sub globose to ovoid. The colour of the spore varies from dirty yellowish brown to brown. Presence of single wall layer with surface ornamented with multiple irregular warts. 


\section{Gigaspora Nigra (J. F. Redhead)}

The size of the spore is between $550 \times 550(\mu \mathrm{m})$. The spore shape varies between globose to sub globose. The colour of the spore varies from dirty yellowish brown to dark brown. Presence of single wall layer with warts. Subtending hypha is present.

\section{Gigaspora Gigantea (Nicol. and Gerd.) Gerd. and Trappe}

The size of the spore is between $750 \times 750(\mu \mathrm{m})$. The spore shape varies between globose to sub globose. The colour of the spore varies from dirty yellowish brown to brown. Presence of double wall layer with surface ornamented with evenly distributed warts.

\section{Gigaspora Decipience (Hall and Abbott)}

The size of the spore is between $300 \times 300(\mu \mathrm{m})$. The spore shape varies between globose to sub globose. The colour of the spore varies from pale yellow to brownish yellowish. Presence of three wall layers, the wall layer is warty. Subtending hypha is present.

\section{Entrophospora sp.}

The size of the spore is between $300 \times 100(\mu \mathrm{m})$. The spore shape is flattened ellipsoid. The colour of the spore is yellowish brown. Single wall with multiple layers. Hyaline spore wall.

\section{Pacispora sp.}

The size of the spore is between $130 \times 100(\mu \mathrm{m})$. The spore shape varies between globose to sub globose to ovoid. The colour of the spore is dirty yellowish brown to yellowish brown. Presence of single wall layer with irregular warts.

Soil is the reservoir of the essential nutrients which are required for the plant growth and development. The present investigation shows that there was variation in the soil nutrient status along different collection sites. Changes in the soil properties vary due to the variation in biotic as well as abiotic factors prevalent in nature. The results show that the samples collected from agricultural farmland had higher organic Carbon percentage, Available Nitrogen (kg/hac), Available Phosphorus ( $\mathrm{kg} / \mathrm{hac})$ as well as Available Potassium (kg/hac). The $\mathrm{pH}$ of the soil was found to be higher along the roadside as well as riverside. The $\mathrm{pH}$ of the soil influences almost every characteristic of soil that is affected by multiple biological interactions within the rhizosphere. The influencing effects of $\mathrm{pH}$ in the rhizosphere are crucial in supporting a biologically diverse microbial community. Manipulation of the $\mathrm{pH}$ by plant roots is constantly occurring and, it is usually believed that plants manipulate the soil $\mathrm{pH}$ in order to change the availability of nutrients; it also undoubtedly influences the abundance and diversity of associated microorganisms (Kent and Triplett, 2002). Soil fertility is inter alia dependent on the soil organic content. The organic carbon releases nutrients for plant growth and helps in promoting the structural, biological and physical health of the soil. The amounts of soil organic carbon present in the soil can vary according to the changes in temperature, rainfall, land management, soil nutrition and soil type and landscape. Carbon stored in the soil as organic carbon also aids in carbon sequestration. Phosphorus is an essential macronutrient which is required for plant nutrition. It contributes in various metabolic processes such as photosynthesis, energy transfer, and synthesis and breakdown of carbohydrates. It is available in both organic well as inorganic form in the soil. However, the amount of readily available phosphorus is very low compared with the total amount of phosphorus in the soil. Nitrogen is also an important plant nutrient for crop production. Nitrogen is a macronutrient responsible for plant 
Oroxylum Indicum (L.) Benth Ex Kurz Growing under

Different Natural Habitat in Northeast India

growth and nutrition. It is also a constituent of the building blocks of almost all plant structures and an essential component of chlorophyll, enzymes, proteins, etc. Nitrogen occupies a unique position as a plant nutrient because rather high amounts are required compared to the other essential nutrients. It stimulates root growth and crop development as well as uptake of the other nutrients. Potassium is another essential plant nutrient and is required in large amounts for proper growth and reproduction of plants. Rhizosphere is a narrow zone of soil affected by the presence of plant roots. The rhizosphere is known to be a hot spot of microbial activities. Plants live in association with a rich diversity of microorganisms during their entire development (Johnson et. al, 1997). This is caused by an increased nutrient supply for microorganisms, since roots release a multitude of organic compounds (e. g. exudates and mucilage) derived from photosynthesis and other plant processes (Brimecombe et. al, 2007). Mycorrhizal symbiosis plays a key role in nutrient cycling in the ecosystem and also protects plants against environmental and cultivation stress (Carvalho et. al, 2004) Certain soil microbes like beneficial bacteria and fungi can improve plant performance under stress environments and consequently, enhance yield (Kaligaric et. al, 2008).

Soil microbes act as an essential component of plant community variety and productivity (Wardle et. al, 2004). The environmental factors such as the soil $\mathrm{pH}$, moisture, temperature, organic carbon and nitrogen play an important role in the distribution of microorganisms (Gaddeyya et. al, 2012). These are the main factors affecting the microbial population and diversity. A total of 23 species of AM fungi belonging to four genera viz., Glomus, Acaulospora, Gigaspora, Entrophospora and Pacisporawere recovered from the rhizosphere of $O$. indicum. Amongst the various AM fungi harboured in the soils of study sites, Glomus sp. was mostly associated in the rhizosphere of $O$. indicum. The study shows that the Glomus sp. was mostly present in the rhizosphere of $O$. indicum followed by Acaulospora sp. and Gigaspora sp. (Manoharachary et. al, 2002) also reported that Glomus as the dominant species in various ecosystem of India. The Glomus spp. might be dominant due to their sporocarpic or clustered nature that helps in sporulation more frequently than rest of the genera as they appear singly in nature. Similarly, Das and Highland (2010) also reported the dominance of Glomus spp. associated with Michelia champaca L. in north-east India. Dhar and Mridha (2006) also reported the same reason for the dominance of Glomus spp. in their study.

The roots of Oroxylum indicum were colonized by AM fungi in all the sites. It was earlier reported by Pawaar and Kakde (2012) that the root of $O$. indicum does not show any type of mycorrhizal associations at all. But this study shows the presence of hyphal, arbuscular as well as vescicular colonization in the roots of the target plant species which is also in confirmation with (Reddy et. al, 2015). Based on literature review, five different habitats were classified mainly roadside, riverside, forest fringe, hill slopes and agricultural farmland for this study. As the symbiotic association between microorganisms and the medicinal plants is of great significance, the study shows the degree of dependence of medicinal plants on the fungal symbionts varies with the prevailing environmental conditions, particularly soil fertility conditions (Debi and Parkash, 2017). In the present study, it was found that AM spore count was maximum in forest fringe and agricultural farmland. The hyphal and arbuscular colonization percentage was again higher in soil samples collected from agricultural farmland, while vescicular colonization percentage was maximum in agricultural farmland and forest fringe areas. The AM spore count of the rhizospheric soil sample of $O$. indicum growing near roadside showed positive correlation with root colonization. AMF behaviour is affected by soil $\mathrm{pH}$ and influence mycorrhizal establishment and growth. The root colonization and the AM spore count were also positively correlated which is in confirmation with earlier finding (Sivakumar, 2013; Carrenho, 2007). It may limit the availability of nutrients; influence the pattern of absorption of nutrient and their exchange in root zone and even distribution of AMF species. The statistical analysis of the data revealed 
that the AM spore count is positively correlated with the soil nutrient status of the samples collected from various collection sites. The correlation value of $(0.766,0.413$, and 0.567$)$ was obtained when root colonization was compared with soil organic carbon percentage, soil nitrogen and potassium content. Similar findings were also reported by Basumatary et. $a l$, 2014. Similarly the available phosphorus in the soil were positively correlated with root colonization, with correlation values of 0.387 and respectively. This is in negation to similar earlier studies by other researchers (Aliasgharzadeh et. al, 2001; Khakpour and Khara, 2012) where negative correlation values were observed between mycorrhizal root colonization (\%) and available soil phosphorus. The positive correlation between soil P and AM colonization, contrary to early observations, could be due to the fact that an increase in P levels in P deficient soils can enhance mycorrhization before an expected decrease occurs (Bolan, 1991). The trees growing along riverside showed negative correlation values when soil $\mathrm{pH}$, Org. Carbon (OC), and N, P, K status were correlated with AM spore count $\left(\mathrm{R}^{2}=-0.12,-0.34,-0.33,-0.581,-0.99\right)$, while AM spore count was positively correlated with colonization. The $O$. indicum trees growing along forest fringe area, AM spore count was positively correlated with soil Org. Carbon while negative correlation values were obtained when AM spore count was compared with soil $\mathrm{pH}$ and $\mathrm{N}, \mathrm{P}, \mathrm{K}$, status. There are several reports that soil $\mathrm{N}$ could suppress root colonization by AM fungi (Chambers et. al, 1980; Buwalda and Goh, 1982; Johnson, 1984). The suppressive effect of soil $\mathrm{N}$ on AM fungi has been attributed primarily to $\mathrm{pH}$ changes associated with variations in soil $\mathrm{N}$ (Thompson, 1986). Fluctuations in the number of AM fungal spores would be expected to occur if they were lost during periods of mycorrhizal formation, or as a result of predation by soil micro-organisms, as well as due to the impact of adverse soil conditions during periods of inactivity (Brundrett, 1991). The trees growing along hill slopes showed positive correlation values for soil pH, Org. Carbon, soil Potassium and AM spore count while negative correlation values were obtained when $\mathrm{AM}$ spore count were compared with soil $\mathrm{N}$ and $\mathrm{P}$ status and root colonization. While slight negative correlation value was obtained when root colonization as well as spore count were compared with $\mathrm{pH}$ of soil. Ghorbani et. al, (2012) and Khakpour and Khara (2012)also reported similar findings. The negative correlation between mean spore density and available soil P recorded in the hill slope is in agreement confirmation with the findings of Nemec et al (1990) and Khade and Rodrigues (2009), who reported similar findings while studying the distribution and ecology of AM fungi in Citrus nurseries and spatio-temporal variations of AM fungi in papaya plantations. In trees growing along agricultural farmland the AM spore count was positively correlated with soil OC and N, P status while it was negatively correlated with soil $\mathrm{pH}$ and K status. Soil K is often reported to have a stimulatory effect on mycorrhization (Furlan and Bernier-Cardou, 1989) and a minimum soil $\mathrm{K}$ is often a prerequisite for mycorrhization in some plant species (Ouimet et. al, 1996). Further studies are in progress to study and characterize different AM species associated with medicinal plants and their application as effective bioinoculants.

\section{ACKNOWLEDGEMENT}

Authors are thankful to Rain Forest Research Institute (Indian council of Forestry Research \& Education), Jorhat, Assam for providing the all possible laboratory facilities and experimental field for carrying out the research work. 
1. Ryan, P. R., Delhaize, E. (2001). Function and mechanism of organic anion exudation from plant roots. Ann. Rev. Pl. Physiol. Mol. Biol. 52,527-560.

2. Schubler, A., Schwarzott, D., Walker, C. (2001). A new fungal phylum, the Glomeromycota: phylogeny and evolution. Mycol. Resrc. 105, 1413-1421.

3. Jakobsen, I., Abbott, L. K., Robson, A. D. (1992). External hyphae of vesicular-arbuscular mycorrhizal fungi associated with Trifolium subterraneum L., Spread of hyphae and phosphorus inflow into roots. New Phytol. 120, $371-380$.

4. Subramanian, K. S., Charest, C. (1999). Acquisition of $N$ by external hyphae of an arbuscular mycorrhizal fungus and its impact on physiological responses in maize under drought-stressed and well-watered conditions. Mycorrhiza. 9, 69-75.

5. Liu, A., Hamel, C., Hamilton, R. I., Ma, B. L., Smith, D. L. (2000). Acquisition of Cu, Zn, Mn and Fe by mycorrhizal maize (Zea mays L.) grew in soil at different P and micronutrient levels. Mycorrhiza. 9, 331-336.

6. Miransari, M., Bahrami, H. A., Rejali, F., Malakouti, M. J. (2009). Effects of arbuscular mycorrhiza, soil sterilization, and soil compaction on wheat (Triticum aestivum L.) nutrients uptake. Soil \& Tillg. Resrc.104, 48-55.

7. Veresoglou, S. D., Shaw, L. J., Sen, R. (2010). Glomus intraradices and Gigaspora margarita arbuscular mycorrhizal associations differentially affect nitrogen and potassium nutrition of Plantago lanceolata in a low fertility dune soil. Pl. Soil. $340,481-490$.

8. Kim, K., Yim, W., Trivedi, P., Madhaiyan, M., Boruah, H. P. D., Islam, M. R. (2009). Synergistic effects of inoculating arbuscular mycorrhizal fungi and Methylo bacterium oryzae strains on growth and nutrient uptake of red pepper (Capsicum annuum L.) Plant and Soil. 327, 429-440

9. Lingua, G., Agostino, G. D., Massa, N., Antosiano, M., Berta, G. (2002). Mycorrhiza-induced differential response to a yellows disease in tomato. Mycorrhiza. 12, 191-198.

10. Li, H., Ye, Z. H., Chan, W. F., Chen, X. W., Wu, F. Y., Wu, S. C., Wong, M. H. (2011). Can arbuscular mycorrhizal fungi improve grain yield, As uptake and tolerance of rice grown under aerobic conditions? Environmental Pollution. 159, 25372545 .

11. Barker, S. J., Tagu, D. (2000). The roles of auxins and cytokinins in mycorrhizal symbioses. J. of Pl. Grwth. Reglatn. 19, 144154.

12. Degens, B. P., Sparling, G. P., Abbott, L. K. (1996). Increasing the length of hyphae in a sandy soil increases the amount of water-stable aggregates. Appld. Soil Ecol., 3, 149-159.

13. Dalal, N. V., Rai, V. R. (2004). In vitro propagation of Oroxylum indicum Vent. a medicinally important forest tree. J. For. Res. 9, 61-65.

14. Ahad, A., Ganai, A. A., Sareer, O., Najm, M. Z., Kausar, M. A., Mohd, M., Siddiqui, W. A. (2012). Therapeutic potential of Oroxylum indicum: a review. J. Pharm. Res. Opin. 2 (10), 163-172.

15. Chauhan, N. S. (1999). Medicinal and Aromatic plants of Himachal Pradesh. $1^{\text {st }}$ edn. New Delhi: Indus Publishing,; 96-298.

16. Bennet, S. S. R., Gupta, P. C, Rao, R. V. (1992), Venerated plants, ICFRE, Dehradun. pp. 147-149.

17. Jayaram, K., Prasad, M. N. V. (2008). Genetic diversity in Oroxylum indicum (L.) Vent. (Bignoniaceae), a vulnerable medicinal plant by random amplified polymorphic DNA marker. African J. Biotechnol. 7(3), $254-262$. 
18. Pawaar, J. S. , Kakde, U. B. (2012). Study of arbuscular mycorrhiza associated with some important medicinal plants in suburban area of Mumbai. Online International Interdisciplinary Research Journal. 2(2), 116-127.

19. Gerdemann, J. W., Nicolson, T. H. (1963). Spores of mycorrhizal endogone extracted from soil by wet sieving and decanting. Trans. Brit. Mycol. Soc., 46, 235-244.

20. Adholeya A., Gaur, A. (1994). Estimation of VAM fungal spores in soil. Mycorrhiza News. 61, 10-11.

21. Phillips, J. M., Hayman, D. S. (1970). Improved produces for clearing roots and staining parasitic and VAM fungi for rapid assessment of infection. Trans. Brit. Mycol. Soc. 55, 158-161.

22. Kent, A. D., Triplett, E. W. (2002). Microbial communities and their interactions in soil and rhizosphere ecosystems. Annual Review of Microbiology. 56, 211-236.

23. Johnson, N. C., Graham, J. H., Smith, F. A. (1997). Functioning of mycorrhizal associations along the mutualism-parasitism continuum. New Phytol. 135, 575-585.

24. Brimecombe, M. J., De Leij, F. A., Lynch J. M. (2007). Rhizodeposition and microbial populations, in The Rhizosphere: Biochemistry and Organic Substances at the Soil-Plant Interface, 41-93.

25. Carvalho, L. M., P. M., Correia, Martins Louca o, M. A. (2004). Arbuscular mycorrhizal fungal propagules in a salt marsh. Mycorrhiza. 14, 165-170.

26. Kaligaric, M., Bohanec, B., Simonovik, B., S`ajna, N. (2008). Genetic and morphologic variability of annual glassworts (Salicornia L.) from the Gulf of Trieste (Northern Adriatic). Aquatic Botany . 89, 275-282.

27. Wardle, D. A., Bardgett, R. D., Klironomos, J. N., Setala, H., Van der Putten, W. H., Wall, D. H. (2004). Ecological linkages between above ground and below ground biota. Sc., 304 (11), 1629-1633.

28. Gaddeyya, G., Niharika, P. S., Bharathi, P., Kumar, P. K. R. (2012). Isolation and identification of soil mycoflora in different crop fields at Salur Mandal. Adv. in App. Sci. Res., 3, 2020-2026.

29. Manoharachary, C., Kunwar, I. K., Mukerji, K. G. (2002). Arbuscular mycorrhizal fungi-identification, taxonomy criteria, classification, controversies and technology. In: Techniques in mycorrhizal studies. Mukerji, K. G. et al. (Eds.). Kluwer Academic Pub., Netherlands, pp. 249-272.

30. Das, P., Highland, K. (2010). Mycorrhizal colonization and distribution of arbuscular mycorrhizal fungi associated with Michelia champaca L. under plantation system in northeast India. J. For. Res. 21 (2), 137-142.

31. Dhar, P. P., Mridha, M. A. U. (2006). Arbuscular mycorrhizal dependency of some tree species-1. Bang. J. of Agri. Res. 31 (4), 533-543.

32. Reddy, R., Devi, A., Balaraju, Chandraiah, Rajesham, K., Ugandhar. (2015). Vesicular Arbuscular Mycorrhizal Fungi associated with the Medicinal plants of Mahadevpur Reserve Forests of Karimnagar East Division, Karimnagar District in Telangana State of India. Science Research Reporter. 5 (1),14-19.

33. Sivakumar, N. (2013). Effect of edaphic factors and seasonal variation on spore density and root colonization of arbuscular mycorrhizal fungi in sugarcane fields. Ann. Microbiol. 63, 151-160.

34. Carrenho, R., Trufem, S. F. B, Bononi, V. L. R, Silva, E. S. (2007). The effect of different soil properties on arbuscular mycorrhizal colonization of peanuts, sorghum and maize. Acta Botanica Brasilica J. 21(3), 723-730. 
35. Basumatary, N., Parkash, V., Tamuli, A. K., Saikia, A. J., Teron, R. (2014). Arbuscular mycorrhizal inoculation affects growth and rhizospheric nutrient availability in Hevea brasiliensis (Willd. ex A. Juss.) Mull. Arg. clones. International Journal of Current Biotechnology. 2(7):14-21.

36. Aliasgharzadeh, N., Saleh Rastin, N., Towfighi, H., Alizadeh, A. (2001). Occurrence of arbuscular mycorrhizal fungi in saline soils of the Tabriz Plain of Iran in relation to some physical and chemical properties of soil. Mycorrhiza.11, 119-122.

37. Khakpour, O., Khara, J. (2012). Spore density and root colonization by arbuscular mycorrhizal fungi in some species in the northwest of Iran. International Research Journal of Appliedand Basic Sciences. 3(5), 977-982.

38. Bolan, N. S. (1991). A critical review on the role of mycorrhizal fungi in the uptake of phosphorus by plant, Pl. Soil. 134, 189207.

39. Chambers, C. A., Smith, S. E., Smith, F. A. (1980). Effects of ammonium and nitrate ions on mycorrhizal infection, nodulation and growth of Trifolium subterraneum. New Phytol. 85, 47-62.

40. Buwalda, J. G., Goh, K. M. (1982). Host fungus competition for carbon as a cause of growth depressions in vesiculararbuscular mycorrhizal ryegrass. Soil Biology and Biochemistry. 14,103-106.

41. Johnson, C. R. (1984). Phosphorus nutrition on mycorrhizal colonization, photosynthesis, growth and nutrient composition of Citrus aurantium, Plant and Soil. 80, 35-42.

42. Thompson, J. B. (1986). Soilless culture of vesicular-arbuscular mycorrhizae of cereals: effects of nutrient concentration and nitrogen source. Canadian Journal of Botany.64, 2282-2294.

43. Brundrett, M. (1991). Mycorrhizas in natural ecosystems. Adv. Ecol. Res. 21,171-313.

44. Ghorbani, M. J., Khara, Abbaspour, N. (2012). Effects of season and soil conditions on the mycorrhizal status and colonization of seven grass species, Iran J. Plant Physiol. 2,387-393

45. Khakpour, O., Khara, J. (2012). Spore density and root colonization by arbuscular mycorrhizal fungi in some species in the northwest of Iran. Int. Res. J. Appl. Basic Sci.3, 977-982.

46. Nemec, S., Vu, J. C. V. (1990). Effects of soil phosphorous and Glomus intraradices on growth, nonstructural carbohydrates, and photosynthetic activity of Citrus aurantium. Plant and Soil. 128:257-263.

47. Khade, S. W., Rodrigues, B. F. (2009). Applications of arbuscular mycorrhizal fungi in agroecosystems. Tropical and subtropical Agroecosystems. 10, 337 - 354.

48. Furlan, V., Bernier-Cardou, M. (1989). Effect of $N, P$ and $K$ on formation of endomycorrhizae, growth and mineral content of onion'. Plant Soil. 113, 167-174.

49. Ouimet, R. C., Camiré, Furlan, V. (1996). Effect of soil K, Ca and Mg saturation and endomycorrhization on growth and nutrient uptake of sugar maple seedlings'. Plant Soil. 179, 207-216.

50. Debi, C. and Parkash, V. (2017). Comparative Soil Nutrient Status and Microbiota Associated in the Rhizosphere of Oroxylum indicum growing in Different Natural Habitat in North East India. Int. J. Curr. Microbiol. App. Sci 6 (12): 2627-2640

51. Nabanita, N., \& PK, B. (2016). Ecofriendly Approaches for the Management of Brown Spot of Paddy in Organic Cultivation. 
